\title{
Using the early childhood environmental rating scale as a tool for classroom improvement
}

Brittany K. Lucci

West Virginia University

Follow this and additional works at: https://researchrepository.wvu.edu/etd

\section{Recommended Citation}

Lucci, Brittany K., "Using the early childhood environmental rating scale as a tool for classroom improvement" (2004). Graduate Theses, Dissertations, and Problem Reports. 1976.

https://researchrepository.wvu.edu/etd/1976

This Thesis is protected by copyright and/or related rights. It has been brought to you by the The Research Repository @ WVU with permission from the rights-holder(s). You are free to use this Thesis in any way that is permitted by the copyright and related rights legislation that applies to your use. For other uses you must obtain permission from the rights-holder(s) directly, unless additional rights are indicated by a Creative Commons license in the record and/ or on the work itself. This Thesis has been accepted for inclusion in WVU Graduate Theses, Dissertations, and Problem Reports collection by an authorized administrator of The Research Repository @ WVU. For more information, please contact researchrepository@mail.wvu.edu. 


\title{
Using the Early Childhood Environmental Rating Scale as a Tool for Classroom I mprovement
}

\author{
Brittany K. Lucci \\ A thesis submitted to the \\ Faculty of the \\ Davis College of Agriculture, Forestry and Consumer Sciences \\ at West Virginia University \\ in partial fulfillment of the requirements \\ for the degree of \\ Master of Science \\ in \\ Family and Consumer Sciences \\ Barbara G. Warash, Ed. D., Chair \\ Carol Markstrom, Ph.D. \\ Dottie D. Rauch, M. Ed. \\ Division of Family and Consumer Sciences \\ Morgantown, West Virginia \\ 2004
}

Key Words: Quality Child Care, Teacher Training, Early Childhood Environmental Rating Scale 


\title{
ABSTRACT \\ USING THE EARLY CHILDHOOD ENVIRONMENTAL RATING SCALE AS A TOOL FOR CLASSROOM IMPROVEMENT
}

\author{
Brittany K. Lucci
}

This study's intent was to examine the use of the ECERS as a training tool for classroom improvement. Quality ratings for classrooms were measured using the two ECERS observations with a training session in between. The participants of this study were 15 Educare classrooms from a northern county in West Virginia.

An alpha level of .05 was used in all statistical analysis. The results of the one-tailed paired-sampled t-test of the ECERS displayed two significant findings. A second analysis resulted in additional significant findings, after removing a center from the study.

This was an important study for child care centers and directors. The child care directors of the study learned the importance of having a quality school and now know what is considered high quality. Directors need to be familiar with the quality issues in child care. Using the ECERS as a training device can help them with many issues. 


\section{Dedications}

Dedicated to:

My Husband

Todd Lucci

My Parents

Tom and Julie Dickie

My Sisters

Alicia Smith and Catherine Dickie 


\section{Acknowledgements}

I would like to acknowledge my sincere appreciation to the many people involved in this research project. First and foremost, I would like to thank Dr. Bobbie Warash for her patience, support, encouragement, and guidance. She has been a wonderful mentor and friend. I would like to thank her for all that she has done for me with this project among other things. Without her, this project may not have been possible. She has been an inspiration in my life. I would like to thank Dr. Carol Markstrom for her helpful suggestions and her statistical expertise. She made statistics as painless as possible. I would like to thank Mrs. Dottie Rauch for her helpful suggestions and support. Her understanding and smile made this project easier.

I would also like to thank Melissa Pelliccioni for her friendship and support along the way. You have made teaching fun and exciting. I am thankful I have made such a wonderful friendship along the way. She is a wonderful person and deserves the best of what life has to offer.

I would also like to thank my family and friends for their continuing support on this project. Your kind words and encouragement made it all possible. Thank you for keeping my goal in sight and encouraging me to always try my best.

I would also like to thank my husband, Todd, for his unconditional love and understanding. His love and support through these past years has helped me through it all.

Finally, I would like to thank Dr. Bobbie Warash, again, for offering me the opportunity to work with her and learn from her. She has made a difference in my life and I could never thank her enough for it. She has made my undergraduate and graduate experience here so wonderful that I wish I never had to leave. 


\section{TABLE OF CONTENTS}

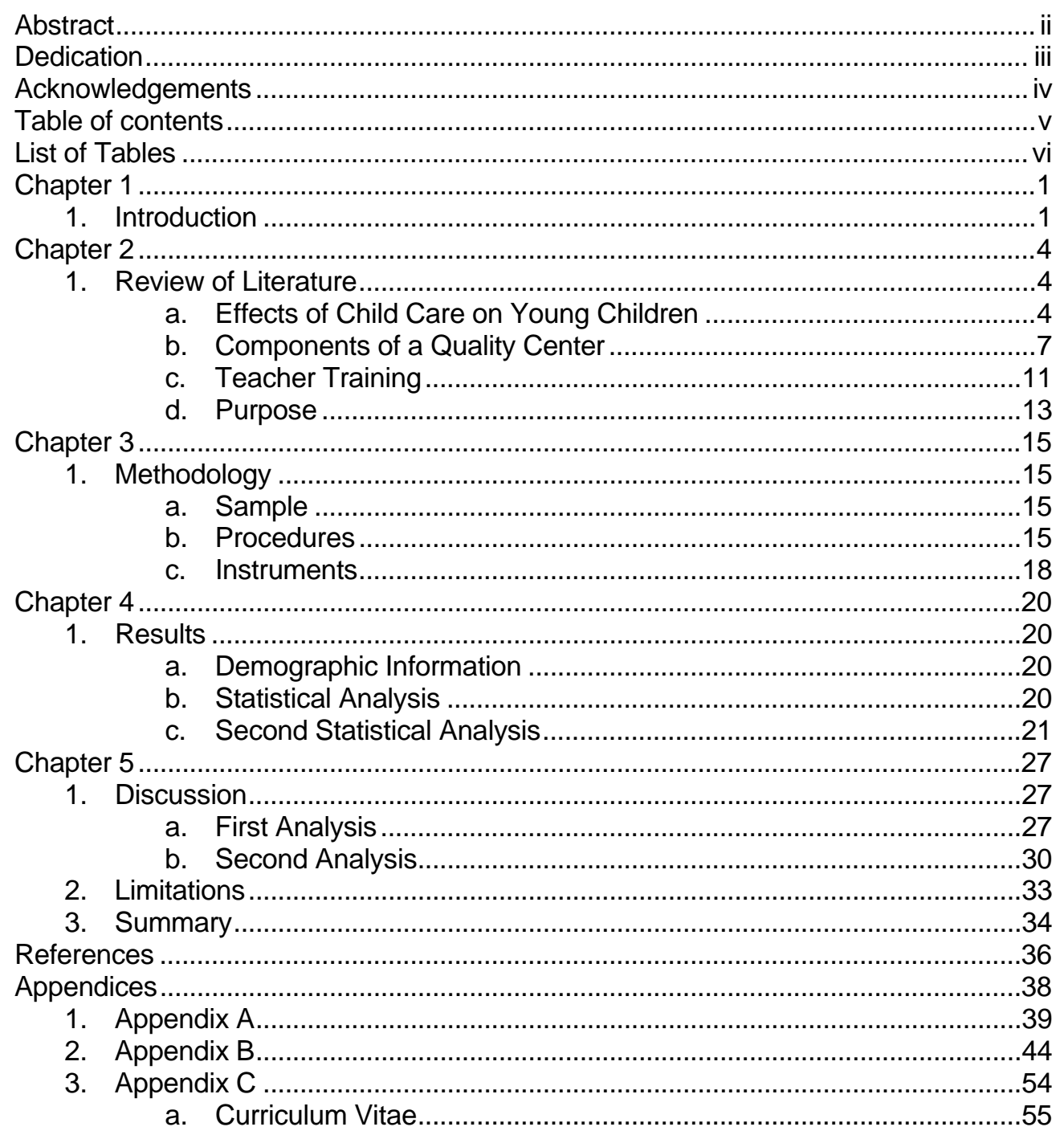




\section{LIST OF TABLES}

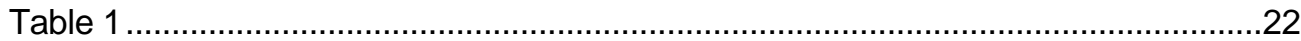

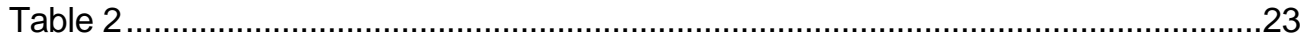

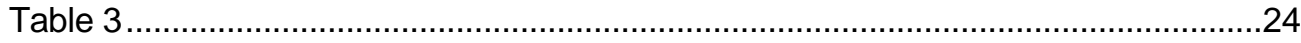

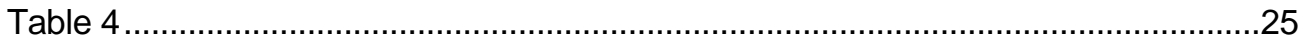




\section{CHAPTER ONE}

\section{Introduction}

Over the past several decades, child care has become an issue of great concern in the field of early childhood development. This is not surprising considering that over half of the children in the United State under the age of six have mothers who are in the work force and require child care for their children, (Boyer, 1993; Spivey, 1998). In addition, such groups as the National Association for the Education of Young Children (NAEYC) have advocated for high quality centers through monitoring processes such as the NAEYC accreditation system. The "widespread public awareness of recent child care research has served as a catalyst for action" (Harms, 2002, p. 3). Unfortunately, many children are placed in child care centers that are not considered to be high in quality. In fact, the average rating of child care centers in the United States has been found to be mediocre (Cryer, 1999). This means that many children being cared for away from home are not enrolled in high quality centers. These centers are often described as unsafe, unsanitary, non-educational, and inadequate in regard to the teacher-child ratio for a classroom. In addition, staff have little training or education in the area of early childhood development. "Poor pay and benefits make it difficult to recruit and hire good early education teachers," which leads to the high turn over rate of teachers and "harms educational quality" (Barnett, 2003, p. 6).

In contrast, children who attend high quality child care centers have numerous benefits such as the development of better cognitive skills, language skills, and social skills (Peisner-Feinberg, Clifford, Burchinal, Yazejian, Byler, \& Rustici, 2003). But 
what constitutes quality child care? Researchers and practitioners agree that it is warm, supportive interactions with teachers in a safe, healthy and stimulating environment where early education and trusting relationships combine to support children's physical, emotional, social, and intellectual development (Bredekamp \& Copple, 1997). Recent research (Harms, 2002) on children's brain development has determined that nurturance and stimulation of children at an early age can have positive and lasting cognitive and social-emotional effects. In order to ensure that a child in early child care or preschool will receive the type of nurturance and stimulation necessary to gain these positive outcomes, the child must be placed in a center that is rated high in overall quality. Research studies conducted on the quality of child care have caught the attention of many states. Some states are now offering some type of reward if a child care center goes beyond the basic standards necessary for a license to operate (Harms, 2002). Their hope is that the centers will improve the quality of care and improve the rating of "mediocre" to that of "good" or "excellent." Another way that states are improving the quality of child care is by enforcing tougher regulations. The "literature has revealed that centers in states with more stringent regulations offer higher quality care, on average, than do centers in states with more lax regulations" (Philips, Mekos, Scarr, McCartney, \& Abbott-Shim, 2000, p. 477). Centers, in these cases, are not given a chance to be mediocre. They must meet these stringent regulations in order to be in operation. This shows that research is influencing the quality of our child care centers nation-wide. Enforcing strict regulations is an effort to improve the early childhood education in our country. Some states are initiating professional development systems where child care 
teachers move along a career lattice depending on the type of trainings and educational programs they attend.

In essence, children who attend high quality centers benefit academically, socially, and emotionally (Barnett, 2003). One of the factors that contribute to a high quality child care center is the educational level of the teaching staff. It is imperative that teachers and directors in child care centers have appropriate education and training so that they use appropriate teaching techniques in their classrooms in order to maintain a quality center. 


\section{CHAPTER TWO}

\section{Literature Review}

The literature review has been divided into three sections: effects of child care on young children, components of a quality child care center, and various training methods for teachers of young children. A number of studies on the quality of child care centers have been reviewed to determine the important issues facing child care center quality and what it takes for a child care center to be rated high in quality.

\section{Effects of Child Care on Young Children}

Numerous studies have been conducted to better understand the effects of child care on the young child. Peisner-Feinberg et al. (1999) were the investigators in charge of the Cost, Quality, and Outcomes Study, a study that is highly regarded when referring to studies on quality of care for young children. The study was conducted to seek understanding on the influence of child care on children. The study began in 1993 with 826 preschool children and was continued through the children's second grade year in elementary school. Because of attrition, the number of children still in the study after the five year longitudinal study decreased to 418. In the researcher's technical report of the study, findings reported that quality care in the preschool years had a great impact on future schooling. For instance, they reported that high quality care aided in better preparation for formal schooling, positively impacts school performance, helps those children who were at risk of not doing well in school, and had positive effects on children's cognitive and social development. 
Research on underprivileged children enrolled in quality child care centers has shown that these children are positively affected, even more so than privileged children. This was one of the major findings of the Cost, Quality, and Outcomes Study (PeisnerFienberg et al., 1999). Children whose mothers had a low level of education were of particular interest in the study. Their analyses showed that an improvement in math skills and fewer problem behaviors were exhibited among children in high quality child care whose mothers had fewer years of education, when compared to children with mothers of lower education in lower quality child care centers.

Additional findings in a study by Burchinal, Roberts, Riggins, Zeisel, Neebe, and Bryant (2000) found "evidence that the quality of the child's environment in child care plays an important role in cognitive and language development" (p. 352). This study included 89 African American infants at the beginning of the study and followed their progress up through the age of three. The measurements used in this particular study involved the Bayley Scales of Infant Development for measuring cognitive development and both the Sequenced Inventory of Communication Development-Revised (SICD) and Communication and Symbolic Behavior Scales-Research Edition (CSBS) to measure language skills. To evaluate the quality of the child care environments, the study utilized the Infant Toddler Environmental Rating Scale (ITERS) and Early Childhood Environmental Rating Scale (ECERS). The increase of quality in the centers these children attended seemed to impact the children's cognitive and language skills over time.

One study involving the Smart Start Program (Bryant, Maxwell, Taylor, Poe, Peisner-Feinberg, \& Bernier, 2003), looked at quality of care for 512 preschool children 
in 110 preschool child care programs. They used the ECERS to assess the quality of the classrooms and used a variety of assessments to measure the children's knowledge and skills. Some of these assessments included the North Carolina School Readiness Assessment developed by Maxwell, Bryant, Ridley, and Keyes-Elstein in 2001, Gresham and Elliott's Social Skills Rating System, the Peabody Picture Vocabulary Test III (PPVT-III), and the Applied Problems subtest of the Woodcock-Johnson developed in 1989. One of the major conclusions of this study was "children who attended higher quality centers scored significantly higher on measures of skills and abilities that are important for school success compared to children from lower quality centers" (Bryant et al., 2003, p. 14).

Researchers have been determined to find the components that are responsible for higher cognitive, language, and social skills of children who attend child care. They have found many quality components that may be linked to children acquiring these skills. When referring to the idea of school readiness upon entry to elementary school, the effects of home experiences with a child's family are the most influential, (Pianta, 2003). Home interactions influence the development of emergent literacy skills, attention span, social skills, and self-control among many other skills necessary for interactions in the public setting. By attending an early education program, such as a high quality child care center or preschool, a child's skills can be enhanced. A supportive and stimulating environment can expand upon the skills the child has acquired from his or her home experiences. The components that make up the requirements for a center to be rated high in quality have been researched so children can receive a high quality early education program and the benefits that will come with it. In turn, measurements have been 
developed to determine the quality of an early child care facility. The researchers and professionals in the child development field hope to educate others in order to better supply our young children with high quality care outside of the home. Also, their research findings will help set the standards for child care centers to operate and allow future early childhood educators to understand the importance of running a high quality center.

\section{Components of a quality center}

Recent studies have shown that there are many variables that constitute a high quality center. These studies acknowledge that teacher salaries, teacher-child ratios, teacher training and education, group size, parent fees, and geographical location all have some impact on determining the level of quality a child care center is rated (Barnett, 2003; Cryer, 1999; Cryer, Tietze, Burchinal, Leal, \& Palacios, 1999; Kellogg, 1999; Philips, Mekos, Scarr, McCartney, \& Abbott-Shim, 1995; Spivey, 1998). Debby Cryer (1999), a leading expert in the field of early childhood education, includes in her definition of quality, the importance of a teacher acting as a facilitator of children's play. In her view, teachers should be there to encourage children to learn and explore the environment while providing a safe and pleasant atmosphere.

In a study by Wiltz \& Klein (2001) that involved 16 centers in the Mid Atlantic states, researchers found that even young children can identify components of high quality centers. This study included eight pre-determined high quality (HQ) centers and eight pre-determined low quality (LQ) centers. Quality ratings were derived from the Early Childhood Environmental Rating Scale (ECERS) and the Classroom Practices 
Inventory Scale (CPI). The researchers asked the children at these sites questions like, "What do you do at child care," "What do you like best about child care or school," and "What don't you like about school?" Children from the LQ centers identified the mandatory activities as being less fun, where as the children from the HQ centers depicted the same activities, which were free choice activities, as being more enjoyable. Another study conducted in Florida using 150 child care programs (Howes \& Smith, 1995), found that the "children's cognitive activity is enhanced within child care classrooms rich in creative play activities and staffed by teachers who engaged the children in positive social interaction" (p. 399). The observers in this study used the ECERS to rate the preschool classroom level of quality and the ITERS to rate the infanttoddler level of classroom quality. In addition to classroom quality, that Attachment QSet (AQS) was used to determine the quality of the relationship between each child and the primary teacher.

Phillipsen, Burchinal, Howes and Cryer, (1997) found that teachers with higher wages were the ones who were most qualified to teach early childhood education. These teachers have been taught how to teach in the most effective and developmentally appropriate ways because of their level of education, their training, and previous experience with teaching young children. They understand how children develop, what their learning capacities are, and the developmental stages children encounter during their early childhood years. These teachers are often teaching in schools that have a higher quality rating. The schools that obtain high quality ratings are often the ones that have the resources to support a high quality learning environment, including the well-educated and highly trained teacher. 
Philips, Mekos, Scarr, McCartney, and Abbott-Shim (2000) conducted a study using 104 centers in Boston, Massachusetts, Atlanta, Georgia, and central parts of Virginia. The purpose of their study was to determine the "importance of ratios, teacher training, and groups size for high quality classroom processes" (p. 475). The Early Childhood Environmental Rating Scale (ECERS) and the Infant Toddler Environmental Rating Scale (ITERS) were used to determine the quality of each of the centers involved. Interviews with each of the center's directors were conducted to find out how much the full-time teachers were paid. The teachers also were to report their highest level of formal education. They found that higher paid teachers seemed to be teaching in the higher quality classrooms across all age groups. They considered this finding helpful in predicting quality classroom. Early childhood educators are more likely to take a job that pays well and can support their beliefs in appropriate teaching methods.

"Better-educated teachers have more positive, sensitive and responsive interactions with children, provide richer language and cognitive experiences, and are less authoritarian, punitive and detached" according to Barnett (2003, p. 4). Apparently, these teachers have learned what the appropriate methods of teaching are, how to handle behavioral problems properly, and what it takes to develop a good relationship with the parents of the children, among many other aspects about working with young children. One of the most important aspects early childhood educators learn in their training is the use of developmentally appropriate practices (DAP). DAP was formulated to create standards for working with young children. The term developmentally appropriate practice has been used by early childhood educators to define what type of activities, teaching methods, and learning experiences are appropriate for specific age groups. 
NAEYC has offered three criteria a teacher must consider about the children in the classroom. He/she needs to consider "what is known about child development and learning," "what is known about the strengths, interests, and needs of each individual," and "knowledge of the social and cultural contexts in which children live" (Bredekamp \& Copple, 1997, p. 36). Incorporating these types of information improves the likelihood that a center will have a higher quality rating.

It is obvious to researchers that there is more than one component of quality necessary to change a center's rating of poor or mediocre quality to a rating of good or excellent. There are many components of quality that affect how a center is rated. One of the leading researchers in the field of early childhood education is Dr. Thelma Harms. She has been in the field for over 45 years and has many noted accomplishments (Frank Porter Graham Child Development Institute, 2003). She, along with Debby Cryer and Richard Clifford, developed a frequently used environmental assessment tool called the Early Childhood Environmental Rating Scale-Revised (ECERS-R). This scale evaluates many of the components that have been recognized as affecting a preschool's overall quality. This scale, along with three other scales developed by Harms and her colleagues, "are being used for training and technical assistance in every state and at least a half-adozen countries” (Frank Porter Graham Child Development Institute, 2003, p. 18).

Each of the above studies mentioned has found important components that seem to predict the quality rating of a center. These are the components that assessors need to look at when evaluating the quality of a center. There are two types of quality that researchers need to look at in a child care center. These two types are structural quality and process quality. 
Structural quality includes items such as teacher's wages, classroom group size, teacher-child ratio, parent fees, and teacher education and training, as suggested by Phillips, Mekos, Scarr, McCartney, and Abbott-Shim, (2001). These quality indicators can easily be assessed by walking into a classroom and talking with the teacher(s) and director. These can also be easily regulated by an outside authority. Process quality is somewhat harder to observe and regulate. This involves watching how the teacher interacts with the children and with the children's parents, what type of lessons and activities are taught, what the daily routine involves, and what type of materials are readily available for the children.

\section{Teacher training}

Components of a quality child care center have been identified and teacher training and education has been recognized as one of the factors that has a direct influence on quality. Unfortunately, less than half of all early childhood teachers have obtained a four-year degree in early childhood education and many have no college education at all (Barnett, 2003). Some child care teachers have on-the-job training such as the United States Apprenticeship for Child Development Specialist Program or Child Development Associate credential (CDA), but the majority of the states only require a high school diploma to teach in a licensed child care center (Barnett, 2003).

A number of studies, such as Rhodes and Hennessy's (2000) study on the effects of specialized training have found that teachers who have had some form of early childhood education training show higher levels of teacher sensitivity towards children and better play interactions among the children. In this particular study, 33 early 
childhood caregivers were separated into two groups; one group received specialized training in early childhood education and the other group was used as the control group. The Caregiver Interaction Scale (CIS) was used to measure how well the teachers interacted with the children. The children were rated using the Peer Play Scale (PPS) to detect a change in peer group socialization. Their results concluded that "the completion of a 120-hour training program resulted in higher levels of caregiver sensitivity and higher levels of play among children cared for by the caregivers that received training" (Rhodes \& Hennessy, 2000, p. 571).

Another study (Burchinal, Howes, \& Kontos, 2002) used data from two similar studies; these studies were the Family Child Care Study and the California Licensing Study. Both of these studies used the Family Day Care Environmental Rating Scale developed by Harms and Clifford (1989) and the Caregiver Involvement Scale developed by Arnett (1989). The purpose of these two separate studies was to identify "structural characteristics that predict observed quality in child care homes, and testing whether child care homes that meet professional recommendations regarding adult:child ratios provide higher quality care" (Burchinal et al., 2002, p. 94). The study suggested that caregiver's training or educational background were "better predictors of child care quality” (Burchinal et al., 2002, p. 99).

Child care directors also need the necessary knowledge of developmentally appropriate practice to supervise and support teachers. One of the complaints of many child care teachers is that their administrators do not support or understand developmentally appropriate practice. There are many initiatives to improve the quality of care and education for young children by states and localities building early childhood 
training systems. Some of these initiatives pertain to leadership and the Administrator/Director Credential. Currently there are 19 states that have a director credential and 19 others who are in the process of developing a director credential for their own state (Tayman \& Lemoine, 2003).

Many systems provide technical assistance, seminars in child care administration, resources on state policy and career development opportunities. West Virginia's Star Registry System (STARS) is an example of how states can develop a process that allows early childhood educators to be placed on a career lattice scale. The STARS system has a scale with eight levels. Level one acknowledges that the educator is a high school graduate without specialized training in early childhood education. Level eight acknowledges that the educator has completed and obtains a master's degree in early childhood education. Child care educators move up the scale by attending approved trainings, obtaining a CDA, the Apprenticeship Program or college degrees. These types of initiates are growing because of the recognized need for quality.

Mentoring programs have also emerged as one of the most promising ways to support child care workers in improving the center quality. With mentoring, experienced teachers work with less experienced teachers (National Center for the Early Childhood Work Force, 1995).

\section{Purpose}

Training for child care workers takes many forms. Some child care workers attend college or have the Apprenticeship for Child Development Specialist certificate. Others have a Child Development Associate credential, while many with limited early 
childhood education use local workshops and conferences to improve their skills.

Regardless of the amount of education or training, child care teachers need to stay in tune with current issues and educational practices. This study will examine the effects of using the Early Childhood Environmental Rating Scale (ECERS) as a training device.

This study utilizd a novel approach to Vygotsky's theory by having directors use a system of scaffolding as a means to improve quality in the classrooms. For children, Vygotsky's theory on scaffolding includes providing supportive help to learn to do a particular task or progress on a task. "With scaffolding the task itself is not changed, but what the learner initially does is made easier with assistance (Bedrova \& Leong, 1996, p. 42). As the learner becomes more independent in completing the task, the level of support from the educator decreases. This same theory was applied to training directors to help their teachers acquire the next level on the ECERS. The hypotheses were:

1. The total score on the Early Childhood Environmental Rating Scale will improve after the initial scores and individual improvement plans are reviewed with the director.

2. Each of the seven sub-scale scores will improve after the initial Early Childhood Environmental Rating Scale scores and individual improvement plans are reviewed with the directors. 


\section{Chapter Three}

\section{Methodology}

The sample data for this study was obtained from a larger statewide study in West Virginia on the effects of the state-supported Educare Project. Educare was established in 2000 as a collaborative effort to improve preschool experiences for young children. The state evaluation for Educare consisted of several measures, one of which was the Early Childhood Environmental Rating Scale (ECERS). This study utilized the ECERS scores from participating child care centers of one northern county in West Virginia. This research involved an experimental design involving pre- and post-test scores using the ECERS as the measurement tool.

\section{Sample}

Participants were designated Educare child care classrooms from one northern county in West Virginia. In this county there were five licensed child care centers and 15 different classrooms. The children in the classrooms were between the ages of three and five. The teachers in the classrooms were all females. The educational level of each teacher was not formally recorded but ranged from high school graduate to a bachelor's

degree. This information was verbally collected from the directors of each center prior to each observation.

\section{Procedures}

The participating classrooms were observed using ECERS. Letters that described the entire Educare study were mailed to parents and sent back to the West Virginia 
Prevention Office and Marshall University, the contracted research facilities for the Educare project. Dr. Bobbie Warash, of West Virginia, was in charge of the testing in the northern county used in the study. Child development students from the local university were trained by Dr. Warash and a graduate assistant to use the ECERS as well as other measures. For purposes of this study, only the ECERS scores were used. The training consisted of reviewing the training video, practicing in the training class, and completing a trial practice at the University Child Development Laboratory under the supervision of Dr. Warash. Upon completing the training, students observed assigned Educare childcare classrooms in pairs and compared scores. The ECERS took between three to four hours to complete in each classroom. Examples of the ECERS indicators and scores sheets can be found in Appendix A. Prior to leaving the childcare classroom, the students discussed any discrepancies they had and then came to an agreed score on the ECERS rating. These discussions were held before leaving the classrooms so the students could provide evidence for their reasoning. For example, one student may have missed some exposed outlets. When discussing her score with the other observer, she may learn that the second observer found some outlets that were uncovered. After the observation was completed and scored, an individual training plan was developed for each classroom by Dr. Warash. The procedures for testing and the scores were reviewed by Dr. Thelma Harms, the author of the ECERS, for accuracy. She approved and complimented the testing team for their preciseness.

The original ECERS observation, along with an individualized training plan (Appendix B) and a summary of improvements were shared with the director of each center. In return, the director provided and shared the information with the corresponding 
classroom teacher. The training plan was developed by using the ECERS as a guide. The calculated ECERS score on each indicator was written on the training plan. The training plan included scores for all 43 indicators and requirements to bring the scores on the indicators up one level. Some requirements were very tangible and could be easily reached while others required more specific training. For example, a classroom with outdoor sand play but without an indoor sand area would earn a rating of a three on indicator number 23 (Appendix A). A recommendation on their individual classroom plan would be to provide sand play inside. This could be easily fulfilled by providing an indoor sandbox and a variety of toys for the sand. This would be an improvement that could be obtained without much effort. In contrast, a classroom that received a rating of 3 on discipline (indicator 31, Appendix A) earned this rating because it was observed that the staff did not use physical punishment and they maintained enough control to prevent children from hurting one another. This classroom could earn a higher score on the indicator by setting up the program to avoid conflict and promote age appropriate interaction. This would take more instruction and training and would not be as easily obtained.

The plan addressed all 43 indicators and included a summary sheet to help the director to focus on areas to be improved. Directors received a copy of the plans for each classroom that was observed. In addition to reviewing the plans with the child care director, Dr. Warash discussed specific ways they could meet a higher rating on each indicator. Basically, the directors were learning the ECERS instrument and what constituted a quality center. Discussions lasted approximately two to three hours with each director. 
After all the directors received the improvement plans, a schedule was made to do a second ECERS observation. This observation was only done in this particular county before the final ECERS observations were completed for the Educare Project. The second observations were completed between seven and ten months after the initial ECERS observation (see Appendix C). The second ECERS observations were completed two to four months after the initial training.

\section{Instruments}

The participating classrooms were observed using the Early Childhood Environmental Rating Scale (ECERS). Both structural and process qualities have been broken up into subcategories in the ECERS developed by Harms, Clifford, and Cryer, (1998). This assessment tool has been used in numerous studies to determine quality ratings in nationwide child care centers and preschools. ECERS, along with other tools designed by Harms et al., such as the ITERS, have been used for training and technical assistance in every state and in other countries (Frank Porter Graham Child Development Institute, 2003). The average rating given to schools using this tool has been a four (4) on a Likert Scale of one (1) "Inadequate" through seven (7) "Excellent."

Extensive testing was conducted on the ECERS-R to determine its reliability and validity in a study conducted by the authors of ECERS (Harms et al., 1998). Twenty-one classrooms were used to verify interrater reliability. The findings were as follows:

Overall, the ECERS-R is reliable at the indicator and item level, and at the level of the total score. The percentage of agreement across the full 470 indicators in the scale is $86.1 \%$, with no item having an indicator agreement level below $70 \%$. 
At the item level, the proportion of agreement was $48 \%$ for exact agreement and $71 \%$ of agreement within one point (Harms et al., 1998, p. 2).

The Pearson product moment correlation between two observers in each classroom was .921 , which is considered quite high, (Harms et al., 1998), and means that the test is a reliable measure of child care classroom quality. 


\section{CHAPTER FOUR}

\section{Results}

\section{Demographic Information}

This study included 15 child care classrooms in Monongalia County, West Virginia. All classrooms participating in the study were part of a larger study conducted by the Educare Project. The observed classrooms were occupied by children between the ages of early three's to early five-year olds. Table one and two lists the pretest and posttest ECERS scores for each subscale for the first and second statistical analyses. Table three is a timeline of observation dates and trainings. Table four is a table of center scores by center and subscale.

\section{$\underline{\text { Statistical Analysis }}$}

An alpha level of 0.05 was used for the statistical analysis. The results of the paired-sample one tailed t-test reflected significance in two of the seven sub-scales. The scores for the space and furnishings and the interactions showed significance from the initial ECERS observation to the second ECERS observation after the training was implemented. The remaining subscales were not significant.

As hypothesized, mean scores did increase after training was implemented for all but one subscale. Two findings were statistically significant; one significant finding increased while the other significant finding decreased. The scores for interaction subscale significantly improved from a mean of 4.27 to 5.34 , which was supported by the one-tailed $\underline{t}$-test; $\underline{t}(-1.92)=14, p=.038$ (see Table 1$).$ There was a decline from the pretest to post-test scores for the space and furnishing subscale. The mean decreased from 
4.28 to 3.70 , which showed significance in the one-tailed $\underline{t}$-test; $\underline{t}(1.93)=14, p=.037$ (see Table 1). Although there were not any significant findings for the remaining five subscales in the ECERS, there was a slight increase in each of their means.

\section{Second Statistical Analysis}

A second analysis was conducted because of the inconsistent direction of the scores on the ECERS. There was a dramatic decline in scores that occurred in Center A. This is unusual. Scores would be expected to stay the same at minimum. The second analysis also used an alpha level of .05 in the statistical analysis. A two-tailed pairedsampled t-test was conducted to determine significance among the eight remaining classrooms on their pre- and post-test ECERS scores.

The new results showed significant findings in personal care routines, activities, interaction, and the overall total scores (see Table 2). The scores for the personal care routines subscale significantly increased from a mean of 2.50 to 4.02 , which is supported by the two-tail paired-sampled t-test; $\underline{\mathrm{t}}(-3.382)=7, \mathrm{p}=.012$. For the activities subscale, there was also a significant increase in the means. The first observation had a mean of 2.43 and the second observation had a mean of 3.19. The significance level for this subscale was $.008 ; \underline{\mathrm{t}}(-3.637)=7, \mathrm{p}=.008$. The interaction subscale significantly increased from a mean of 3.30 to 5.34 , which is confirmed by the results of the two-tailed paired-sampled t-test; $\underline{\mathrm{t}}(-2.981)=7, \mathrm{p}=.020$. The overall total means of the seven subscales also showed a significant increase from a mean of 3.15 to $4.12 ; \underline{t}(-3.81)=7, p$ $=.007$. The second analysis did not reveal significance for space and furnishings, language-reasoning, program structure and parents and staff subscales. 
Table 1

Table of Means, Standard Deviations, and One-Tailed t-test for the ECERS

Subscales

\begin{tabular}{|l|c|c|c|c|}
\hline SUBSCALES & MEANS & STD. DEV. & df & ONE-TAILED $\underline{t}$-test \\
\hline Space and Furnishings & 4.28 & 1.14 & 14 & 0.037 \\
Pretest & 3.70 & 0.42 & & \\
Posttest & 3.52 & 1.72 & & 0.088 \\
\hline Personal Care Routines & & 0.67 & & \\
\hline Pretest & 4.20 & 14 & 14 & 0.377 \\
Posttest & 4.20 & 1.78 & & \\
\hline Language-Reasoning & 4.37 & 1.22 & & \\
Pretest & 3.17 & 1.07 & & \\
Posttest & 3.44 & 0.72 & & \\
\hline Activities & & & 14 & 0.172 \\
Pretest & 4.27 & 1.94 & & \\
Posttest & 5.34 & 1.48 & & \\
\hline Interaction & & & 14 & 0.387 \\
Pretest & 4.30 & 2.09 & & \\
Posttest & 4.47 & 1.28 & & \\
\hline Program Structure & & & 14 & 0.113 \\
Pretest & 5.23 & 0.84 & & \\
Posttest & 5.50 & 0.76 & & \\
\hline Parents and Staff & 4.07 & 1.17 & & \\
Pretest & 4.29 & 0.56 & & \\
Posttest & & & \\
\hline Total & & & \\
Pretest & & & \\
Posttest & & & \\
\hline
\end{tabular}

Note: An alpha level of .05 was used. 
Table 2

Table of Means, Standard Deviations, and Two-Tailed $t$-test for the ECERS Subscales for the Second Statistical Analysis

\begin{tabular}{|l|c|c|c|c|}
\hline SUBSCALES & MEANS & STD. DEV. & df & TWO-TAILED $\underline{t}$-test \\
\hline Space and Furnishings & 3.39 & 0.63 & & 0.506 \\
Pretest & 3.59 & 0.48 & & \\
Posttest & 2.50 & 1.16 & & 0.012 \\
\hline Personal Care Routines & & 0.68 & & \\
Pretest & 4.02 & & 7 & 0.146 \\
Posttest & 3.25 & 1.11 & & \\
\hline Language-Reasoning & 4.25 & 1.57 & & \\
Pretest & & & 7 & 0.008 \\
Posttest & 2.43 & 0.46 & & \\
\hline Activities & 3.19 & 0.63 & & \\
Pretest & 3.30 & 1.98 & & \\
Posttest & 5.34 & 1.13 & & \\
\hline Interaction & & & 7 & 0.020 \\
Pretest & 2.61 & 1.01 & & \\
Posttest & 4.06 & 1.41 & & \\
\hline Program Structure & & & 7 & 0.073 \\
Pretest & 4.58 & 0.57 & & \\
Posttest & 5.25 & 0.98 & & \\
\hline Parents and Staff & 3.15 & 0.46 & & \\
Pretest & & & & \\
Posttest & & & \\
\hline Total & & & \\
Pretest & & & \\
Posttest & & & \\
\hline
\end{tabular}

Note: An alpha level of .05 was used. 
$\underline{\text { Table 3: Timeline of Observation Dates and Trainings }}$

April 2001 Observation 1 of Centers B, D, \& E

May $2001 \quad$ Observation of Centers A \& C

June 2001

July 2001

August 2001

September 2001 Training of Center D

October 2001 Training of Centers A, B, \& C

November 2001 Trainings of Center E

Observation 2 of Center D

December 2001

January 2002 Observation 2 of Centers A, B, \& C

February 2002 Observation 2 of Center E 
Table 4: ECERS Pretest and Posttest Scores

\begin{tabular}{|c|c|c|c|c|c|c|c|c|c|}
\hline School & Room & SPFOD1 & SPFOD2 & PCROD1 & PCROD2 & LROD1 & LROD2 & ACTOD1 & ACTOD2 \\
\hline Center A & 1 & 5.00 & 4.25 & 4.67 & 4.33 & 4.50 & 5.25 & 3.00 & 3.88 \\
\hline Center A & 2 & 5.00 & 3.87 & 5.33 & 3.50 & 3.50 & 4.25 & 3.11 & 3.44 \\
\hline Center A & 3 & 5.37 & 3.37 & 3.16 & 4.83 & 7.00 & 5.75 & 4.30 & 4.20 \\
\hline Center A & 4 & 6.25 & 3.62 & 6.50 & 3.66 & 7.00 & 4.00 & 4.22 & 2.90 \\
\hline Center A & 5 & 5.75 & 3.75 & 6.50 & 4.50 & 7.00 & 3.50 & 5.80 & 3.40 \\
\hline Center A & 6 & 4.50 & 4.25 & 4.16 & 5.33 & 5.50 & 4.50 & 3.70 & 3.20 \\
\hline Center B & 9 & 3.13 & 3.25 & 1.83 & 3.33 & 2.75 & 5.00 & 2.10 & 2.70 \\
\hline Center B & 10 & 2.50 & 4.37 & 2.33 & 4.33 & 2.50 & 3.75 & 2.55 & 3.77 \\
\hline Center C & 11 & 2.88 & 3.37 & 4.33 & 3.16 & 3.50 & 2.50 & 2.10 & 2.22 \\
\hline Center C & 12 & 4.38 & 4.25 & 4.33 & 5.00 & 5.25 & 3.25 & 2.30 & 3.00 \\
\hline Center D & 13 & 4.13 & 3.25 & 1.50 & 3.33 & 1.50 & 2.25 & 2.50 & 2.60 \\
\hline
\end{tabular}

\section{Key:}

SPFOD $1=$ SPFOD2 $=$ PCROD1 = PCROD2 = LROD1 = LROD2 = ACTOD1 $=$ $A C T O D 2=$ INTOD1 = INTOD2 = PRSOD1 $=$ PRSOD2 = PSOD1 $=$ PSOD2 = TOTLOD1 $=$ TOTLOD2 =
Spaces and Furnishings observation date 1 Spaces and Furnishings observation date 2

Personal Care Rountines observation date 1

Personal Care Rountines observation date 2

Language-Reasoning observation date 1

Language-Reasoning observation date 2

Activities observation date 1

Activities observation date 2

Interactions observation date 1

Interactions observation date 2

Program Structure observation date 1

Program Structure observation date 2

Parents and Staff observation date 1

Parents and Staff observation date 2

Total Average observation date 1

Total Average observation date 2 
Table 4: ECERS Pretest and Posttest Scores (continued)

\begin{tabular}{|ll|ll|ll|ll|}
\hline \hline INTOD1 & INTOD2 & PRSOD1 & PRSOD2 & PSOD1 & PSOD2 & TOTLOD1 & TOTLOD2 \\
\hline 6.00 & 6.40 & 4.67 & 7.00 & 5.83 & 6.00 & 4.68 & 5.00 \\
\hline 4.80 & 1.40 & 6.66 & 4.74 & 5.83 & 5.50 & 4.75 & 3.78 \\
\hline 4.12 & 4.40 & 5.66 & 4.75 & 5.83 & 5.83 & 5.02 & 4.58 \\
\hline 6.80 & 5.80 & 7.00 & 4.75 & 6.33 & 6.00 & 6.07 & 4.18 \\
\hline 7.00 & 6.20 & 7.00 & 5.00 & 5.83 & 6.00 & 6.24 & 4.45 \\
\hline 5.00 & 6.80 & 7.00 & 4.75 & 6.33 & 5.50 & 4.85 & 4.69 \\
\hline 4.00 & 6.40 & 5.67 & 3.66 & 5.83 & 5.60 & 4.24 & 4.80 \\
\hline 5.60 & 6.40 & 3.33 & 5.66 & 3.67 & 5.83 & 3.76 & 4.69 \\
\hline 1.80 & 5.40 & 2.33 & 2.66 & 5.33 & 6.00 & 2.76 & 3.90 \\
\hline 1.00 & 4.40 & 3.75 & 4.66 & 5.10 & 6.83 & 2.81 & 4.56 \\
\hline 6.60 & 4.50 & 3.33 & 3.75 & 4.33 & 4.33 & 3.64 & 3.35 \\
\hline 4.00 & 6.40 & 1.00 & 5.33 & 4.33 & 4.33 & 3.67 & 4.30 \\
\hline 1.60 & 3.40 & 2.50 & 2.25 & 4.33 & 4.00 & 2.72 & 3.04 \\
\hline 3.00 & 5.80 & 1.33 & 5.50 & 4.33 & 5.33 & 3.07 & 4.72 \\
\hline 2.80 & 6.40 & 3.33 & 2.66 & 5.20 & 5.33 & 2.80 & 4.28 \\
\hline
\end{tabular}




\section{CHAPTER FIVE}

\section{$\underline{\text { Discussion }}$}

\section{First Analysis}

This study examined the effects of using the ECERS as a training tool to improve the quality of child care classrooms. Pre-test and post-test scores on the ECERS were compared to see if the scores improved after a training session with the director to review the initial ECERS scores and the individual improvement plans for their classrooms were introduced. Although the results failed to show statistically significant change in the overall total scores and in five of the subscales, there were slight improvements in the majority of the mean scores. The hypotheses stated:

1. The total score on the Early Childhood Environmental Rating Scale will improve after the initial scores and individual improvement plans are reviewed with the director.

2. Each of the seven sub-scale scores will improve after the initial Early Childhood Environmental Rating Scale scores and individual improvement plans are reviewed with the directors.

Hypothesis one was not supported. Eight of the classrooms obtained higher scores on second ECERS observation (see Table 1). However, the largest center, with seven of the classrooms, had six classrooms where the total ECERS scores went down. This center had very high initial ECERS scores. In fact their initial scores ranged from 4.24 to 6.24 
on the seven point scale. Once their initial scores were revealed in the improvement plan, the center director might have let things slip because of their high ratings. There were slight improvements in the total scores in all but one of the other classrooms but they still failed to reach significance. The other classroom's initial scores ranged from 2.72 to 3.76 .

There are several other reasons that may explain the non-significance on the total scores. It is very hard for centers to make quality changes in a short amount of time and without continuous training. This is a process that probably requires more than a few months. In addition, there were many teacher turnovers which effects classroom quality and if it is a newly hired teacher it requires the director to start over with basic training before proceeding to more advanced issues on quality. The county in the study had a tremendous number of changes in the classroom teaching staff. Of the 15 classrooms observed, there was only one documented classroom without any teacher changes. Every other classroom either had some type of teacher change whether it was a new teacher or an assistant to leave or a teacher or assistant moved to another classroom in the center. It would seem this had to play a role in the results. All the directors stayed the same but the mobility of the teaching staff would interrupt how directors would follow up with the individual plans for the classroom. Teacher turnover has a negative impact on the quality of care (Barnett, 2003).

Hypothesis two consisted of looking at the seven sub-scales of the ECERS for improvements after the individual improvement plans were reviewed with the director for each of their classrooms. The subscales for personal care routines, language-reasoning, activities, program structure, and parents and staff were not significant. Again, the lack of consistency in the teaching staff could have played a major part in these findings. The 
means on the subscale, personal care routines, showed slight improvement. This subscale should be more of a center policy rather than an individual teacher's routine. For example, a child care center should have a hand washing policy that applies to all staff regardless of the age of the children. Directors were given an example of a hand washing policy. The means on the subscale, language-reasoning, also increased slightly . This is a more difficult skill because it requires substantial experience and knowledge about young children. Teachers have to learn to reflect upon their interactions and respond to children in a way to help them grow cognitively. The means on the subscales of program structure, activities and parents and staff also increased, but not enough to be significant.

The subscale of space and furnishings was significant. The scores dropped. Means from the initial observation to the second observation were 4.28 to 3.70 , respectively. Although this portion of the improvement plan would be the easiest to fix because it is the most tangible, it takes monetary resources to produce new chairs, tables, play equipment, and other furniture needed in a child care setting. Many schools do not have the necessary capital to purchase improved equipment. Equipment needed to operate a child care classroom is very expensive and many centers rely solely on parent tuition. It was also interesting to note that of the 10 classrooms that dropped on this subscale, seven were in the largest center. All the classrooms in this center went down on this subscale. The initial scores at this center were high on space and furnishings, but may have dropped between the observations time period of ten months because equipment was not maintained or replaced when needed.

The interaction subscale scores increased. The interaction subscale of the ECERS would be categorized as a process quality component. This involves activities taught 
within a child care classroom, supervision of children's play, disciplinary actions taken on by teachers, individual and group interactions with the children by the teachers, interactions between children, daily routines of the classroom, and the type of materials that are readily available to children. These type of interactions are more difficult to observe and even more difficult to improve upon. It is difficult to explain why this area improved among the classrooms observed. However, it was an area that Dr. Warash emphasized in the individual improvement plans because it is so important in the social development of young children. Interaction was also emphasized as part of the Educare system. Educare provided monthly group trainings for the teachers and directors. Good interactions with children were a major focus for the trainings because positive social interactions are associated with classroom quality (Howes \& Smith, 1995).

\section{Second Analysis}

The second analysis was conducted by removing center A's data and running a two-tailed paired-sampled t-test on the remaining classrooms. This was done to compensate for center A's dramatic decline in scores from observation one to observation two. This center's scores did not reflect the other center's scores of improving from the first observation to the second observation. With the second analysis, there were significant findings in the personal care routines, activities, and interaction subscales as well as for the overall total scores.

Hypothesis one was significant. The overall scores did increase (see Table 2). Seven of the eight centers improved their overall scores from observation one to observation two. It can be concluded that using the ECERS as a training tool is an 
efficient way to help centers improve their scores. Helping directors to recognize the indicators for quality is a direct method of obtaining classroom improvement. Directors, as well as teachers, need to know the quality indicators. After the training with the ECERS, many of the directors purchased the scale so they could become more familiar with the performance indicators.

Hypothesis two investigated each subscale and their individual results. Of the seven subscales, significant findings were found in the following subscales: personal care routines, activities, and interactions. The other four subscales, space and furnishings, language-reasoning, program structure, and parents and staff, did not show any significance.

The personal care routine subscale scores increased significantly. This may have been due to the emphasis placed on these issues during the training session. For example, each director was given an example of a center's hand-washing policy to help them understand the importance of good hygiene. It was also emphasized that a child care facility should have their own center policy so that procedures are consistent or each classroom and all staff. Many issues in this subscale can easily be fixed. For example, exposed electrical sockets are remedied by simply placing the caps over the sockets. These kind of corrections would help to explain the increase of scores.

The activities subscale also increased and resulted in a significant finding. This area of the ECERS looks at appropriate curriculum areas and lessons that are used throughout the day. Items in this section would include fine motor play, block play, music and movement participation, art activities, sand and water play, the dramatic play area, nature and science area, incorporation of diversity, and math and number play. 
Indicators on the ECERS promote the incorporation of these areas into the daily activities of each classroom. Working with the directors on an individual basis using the ECERS indicators provided appropriate guidance to the various curriculum areas. The individual plans for each classroom suggested concrete ways to enhance and include activities that promote the social, cognitive and physical development of children. Also, under the activities subscale in the ECERS, the use of televisions, computers and videos is discussed. The proper use of these items was stressed and limited use for each was encouraged during the training session.

The remaining four subscales did not result in any significant findings. Space and furnishings did not significantly improve. This may be due the lack of readily accessible monetary resources available to a center. High quality furniture and equipment is expensive. Most centers operate on small budgets and must accumulate money over time to purchase long-lasting, durable furniture for their classrooms. These centers only had between two to four months to improve their quality ratings. This may have been too short of time to obtain necessary resources needed to purchase new equipment.

The language-reasoning subscale also did not show any significant findings. This item is a more difficult area to improve. It takes time for teachers to learn how to properly respond to children in order to promote language skills, cognitive developments, and social skills. This skill takes an extensive amount of knowledge and experience with young children. It also requires a teacher to be reflective of his/her own interactions. A teacher must be aware of the child's cognitive understanding and thinking processes in order to respond to his or her questions or discoveries. 
Program structure subscale areas did not show an increase. The program structure portion of the ECERS covers areas such as the daily schedule, how free play is handled, how group time is conducted, and what provisions are taken for children with disabilities. It was discovered that many of the centers often do not think of "free play" as a time when children learn. Directors, especially, cannot seem to let go of the idea that teaching young children must involve direct instruction. The ECERS requires centers to have a minimum of $1 / 3$ of their day, a substantial portion of the day, as free play or unstructured time. This was an area that many teachers did not plan for throughout the day, which caused scores in this area to not progress.

The subscale on parents and staff involves the operation of the child care center as a whole. For example, improvements in this area requires a separate room for a staff lounge, funds available for professional improvement of staff such as trainings or some sort of continuation of formal education, and the fair distribution of staff duties. Some of these areas are difficult to improve and many take large amounts of monetary resources which may not be available. This area also would require more than two to four months for improvement. Many of these indicators include provisions for staff that requires monetary resources. Opportunities for professional growth can be expensive.

\section{$\underline{\text { Limitations }}$}

The primary limitations of this study were the limited sample size and location of the study. Only fifteen classrooms were observed in one county in northern West Virginia, making it impossible to generalize across all locations. Expanding both samplesize and areas covered could dramatically change the results of the study. 
Another limitation of the study was that only the directors of the centers were trained on the individual classroom results. The teachers themselves relied heavily on what the director said and did to make improvements in the school. Effective communication may not have been achieved between the director and the classroom teachers.

As stated earlier, teacher turnover occurred quite often. This changes the atmosphere of the classroom when teachers and assistant teacher change classrooms or new ones are hired. This study would have been better if the teaching staff was more consistent.

Another limitation was that the centers were given only a period two to four months to improve on scores. This may have bee too short of a time to allow for classroom improvement among the centers.

\section{Summary}

In the first analysis, there were improvements in most of the mean scores, although statistical significance was only found in two of the subscales. The means of each subscale, with the exception of spaces and furnishings, did increase at least slightly. Teacher interactions were also improved.

The second analysis showed improvements in all the mean scores, although statistical significance was only found in three of the subscales and in the overall total of subscales. Center A's score were removed for the second analysis because they did not reflect the other center's scores of improvement. 
The ECERS as a training tool can be effective. In child care, quality issues are of great concern and progress is often very slow. Using the ECERS as a training tool can help centers increase their scores and improve their quality rating.

The training that occurred may have helped directors realize the importance of items that are valued in a quality center. Becoming familiar with the ECERS is a positive consequence of this study. Many directors in this study were not familiar with the ECERS and have since purchased a copy. This is a step in the right direction. West Virginia has made the ECERS a mandatory evaluation tool in all public school four-yearold programs so all of their early childhood programs are using the scale. 


\section{References}

Barnett, S., (2003). Better teachers, better preschools: Student achievement linked to teacher qualifications. Preschool Policy Matters, 2, 1-12.

Bedrova, E., \& Leong, D. J. (1996). Tools of the mind: The Vygotskian approach to early childhood education. New Jersey: Prentice-Hall.

Boyer, E. L., (1993). Ready to learn: A mandate for the nation. Young Children, 48, 5457.

Bredekamp, S., \& Copple, C. (Eds.). (1997). Developmentally appropriate practice in early childhood programs (Rev. ed.). Washington, D.C.: NAEYC.

Bryant, D., Maxwell, K., Taylor, K., Poe, M., Peisner-Feinberg, E., \& Bernier, K. (2003). Smart start and preschool child care quality in NC: Change over time and relation to children's readiness. Chapel Hill, NC: FPG Child Development Institute.

Burchinal, M., Howes, C., \& Kontos, S., (2002). Structural predictors of child care quality in child care homes. Early Childhood Research Quarterly, 17, 87-105.

Burchinal, M. R., Roberts, J. E., Riggins, R. Jr., Zeisel, S. A., Neebe, E., \& Bryant, D., (2000). Relating quality of center-based child care to early cognitive and language development longitudinally. Child Development, 71, 339-357.

Cryer, D., (1999). Defining and assessing early childhood program quality. Annals of the American Academy of Political and Social Science, 563, 39-55.

Cryer, D., Tietze, W., Burchinal, M., Leal, T., \& Palacios, J., (1999). Predicting process quality from structural quality in preschool programs: A cross-country comparison. Early Childhood Research Quarterly, 14, 339-361.

Frank Porter Graham Child Development Institute. (2003). Roadmaps to quality. Early Developments, 7, 18-19.

Frank Porter Graham Child Development Institute. (2003). A whole new yardstick. Early Developments, 7, 8-11.

Harms, T., (2000). Defining quality. All Together Now, 6, 3-5.

Harms, T., Clifford, R.M., \& Cryer, D. (1998). Early Childhood Environmental Rating Scale: Revised Edition. New York: Teachers College Press. 
Howes, C., \& Smith, E. (1995). Relations among child care quality, teacher behavior, children's play activities, emotional security, and cognitive activity in child care. Early Childhood Research Quarterly, 10, 381-404.

Kellogg, L. (1999). The Kellogg child development center: High-quality child care. Annals of the American Academy of Political and Social Science, 563, 56-72.

National Center for the Early Childhood Work Force. (1995). Mentoring programs: An emerging child care career path. Compensation Initiatives Bulletin, 1.

Peisner-Feinberg, E.S., Burchinal, M. R., Clifford, R. M., Howes, C., Kagan, S. L., Yazejian, N., Byler, P., Rustici, J., \& Zelazo, J. (1999). The child of the cost, quality, and outcomes study go to school: Technical report. Chapel Hill: University of North Carolina at Chapel Hill, Frank Porter Graham Child Development Center.

Phillips, D., Mekos, D., Scarr, S., McCartney, K., \& Abbott-Shim, M. (2000). Within and beyond the classroom door: Assessing quality in child care centers. Early Childhood Research Quarterly, 15, 475-496.

Phillipsen, L. C., Burchinal, M. R., Howes, C., \& Cryer, D. (1997). The prediction of process quality from structural features of child care. Early Childhood Research Quarterly, 12, 281-303.

Pianta, R.C. (2003). The transition to school: A focus on children, families, schools, and communities. Focus On Pre-K and K, 16, 1-8.

Rhodes, S., \& Hennessy, E. (2000). The effects of specialized training on caregivers and children in early-years settings: An evaluation of the foundation course in playgroup practice. Early Childhood Research Quarterly, 15, 559-576.

Spivey, A. (1998). Is day care good enough? Retrieved August 31, 2003, from http://research.unc.edu/endeavors/spr98/daycare.html

Tayman, B., \& Lemoine, S. (2003, June). State early childhood director credentials. Article presented at the West Virginia Professional Development Retreat by the National Child Care Information Center and Wheelock College, Charleston, WV.

Wiltz, N. W., \& Klein, E. L. (2001). "What do you do in child care?” Children's perceptions of high and low quality classrooms. Early Childhood Research Quarterly, 16, 209-236. 
APPENDICES 


\section{Appendix A}

Examples of ECERS Indicators and Score Sheets 
Inadequate
Minimal

4

Good
6

\section{Sandwater*}

1.1 No provisiont for sand or water play, outdoors or indoors.

1.2 No toys to use for sand or water play.

3.1 Sume provision for sand or water play accessible either outdours or indoors.

3.2 Sume sand toys accessible.

\section{Notes for Clarification}

- Materials that can easily be poured, such as rice, lenuls, bird seed, and cornmeal may be substituted for sand. Sand or sand substitute must be available in sufficient quantity so chuldren can dig in it, fill containers, and pour.

\section{Questions}

(3.1) Do you use sand or water with the children? How is this handled? About how often? Where is this available?

5.1 Provision for sand and water play (either outdoors or indours).

5.2 Varicty of toys accessible for play (Ex. containers, spoons funnels, scuops, shovels, pots and pans, molds, toy people, animals, and tucks).

5.3 Sand or water play available to children for at least 1 hour daily. 7.1 Proviston for sand and wate
play, both indoors and outdours (weather permituing)

7.2 Different activities done wi sand and water (kx. bubble added to water, material in sand table changed, i.e. rice substituted for sand).

$\dagger$ "Provision" tor sand and water requeres action on the part of staff to provid appropriate materials for such play. Allowing chuldren to play us puddiles or dig in the dirt on the playground does not meet the requirements of this tem.

‡ Each room does not have to have its own sand and water table, but must be able to use a sand and water table regularly if it is shared with another room

(3.2) Are there any toys for children to use with sand or water play? Please describe them

(7.2) Do you change the activities children do with sand and water? 


\section{nadequate}

$\cdot 1$
2

31. Discipline

1.1 Children are controlled with severe methods (Ex. spank ing, shouting, confining children for long periods, or withholding food).

1.2 Discipline is so lax that there is little order or control.

1.3 Expectations for behavior are largely inappropriate for age and developmental level of children (Ex. everyone must be quiet at meals; children must wait quietly for long periods of time).
4

3.1 Staff do not use phystcal punishment or severe methods.

3.2 Staff usually maintain enough control to prevent children from hurting one another.

3.3 Expectations for behavior are largely appropriate for age and developmental level of children.

Note for Clarification

- There needs to be general consistency among staff members in the way they handle different situations and children. This does not mean that there can be no flexibility. respect for for positive social interaction in a group, such as no hitting or hurting, respect for others and for materials, should always be followed. A specialized

program may be needed to help a child with a disability follow basic classroom rules. Questions

(1.1) Do you ever find it necessary to use strict discipline? Please describe the methods you use.

(7.2) Do you use activities with the children that encourage them to get along well with

(7.3) What do you do if you have a child with a very difficult Isehavior problem?

5.1 Staff use non-puniuve discipline methods effectively (Iix. giving attention for positive behaviors; redirecting child from unacceptable to acceptable activity)

5.2 Program is set up to avoid conflict and promote ageappropriate interaction (lix. duplicate toys accessible; child with favorite toy given protected place to play).

5.3 Staff react consistently* to children's behavior (Ex. . different staff apply same rules and use same methods; basic rules followed with all children).
6 7

7.1 Statt actuvely involve children in solving their conflicts and problems (lix. help children talk out problems and think of solutions; sensitize children w) feelings of others).

7.2 Staff use activities to help children understand socia skills (IEx. use storybooks and group discussions with children to work through common conflicts).

7.3 Staff seck advice from other professionals concerning behavior problems. 


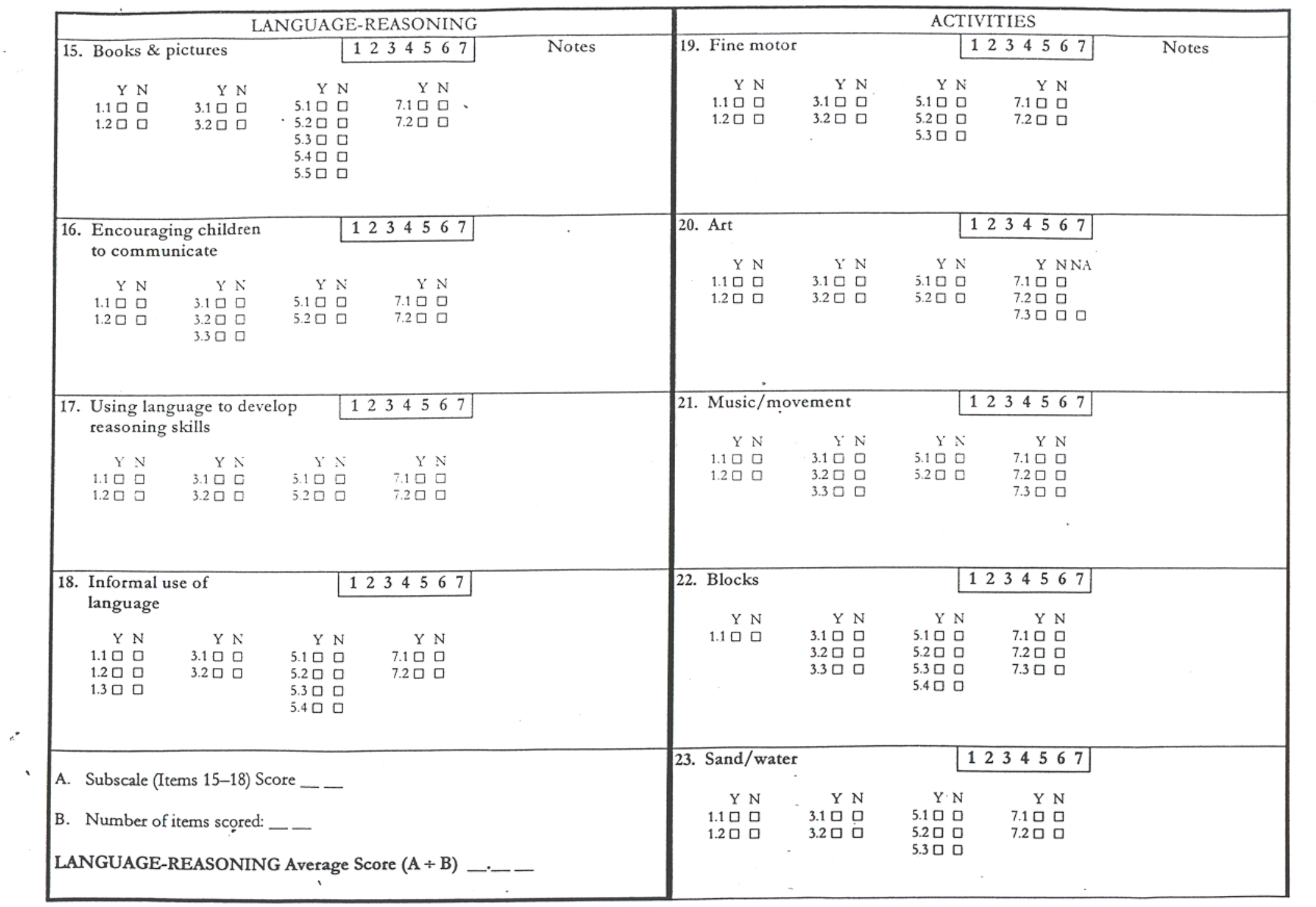




\section{Sample of a Filled-in Score Sheet and Profile}

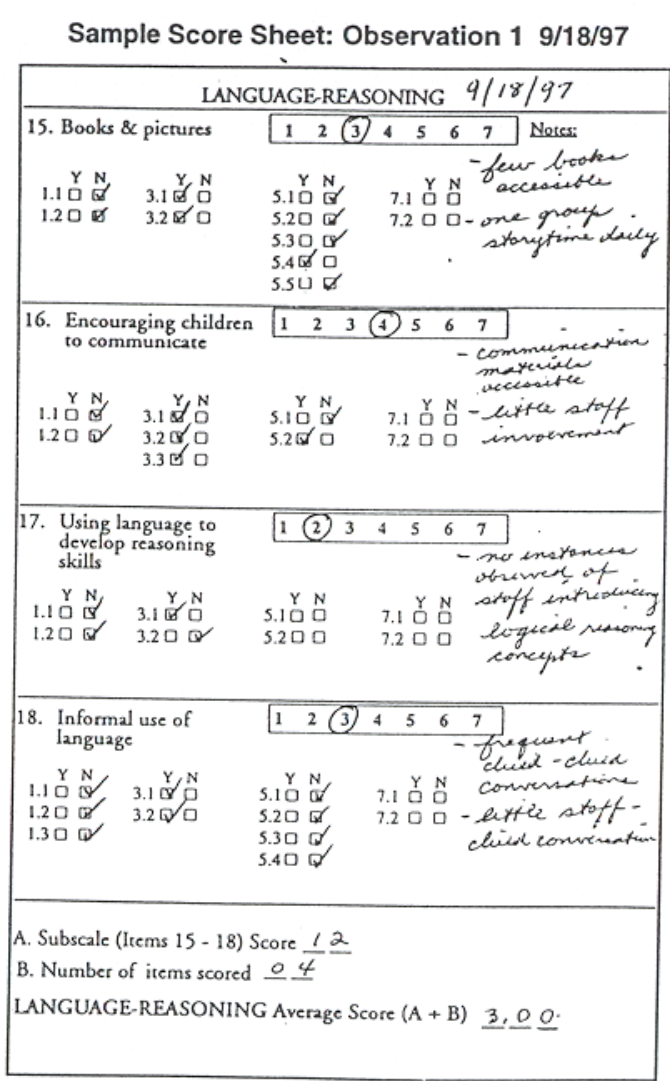

Sample Score Sheet: Observation 2 4/29/98

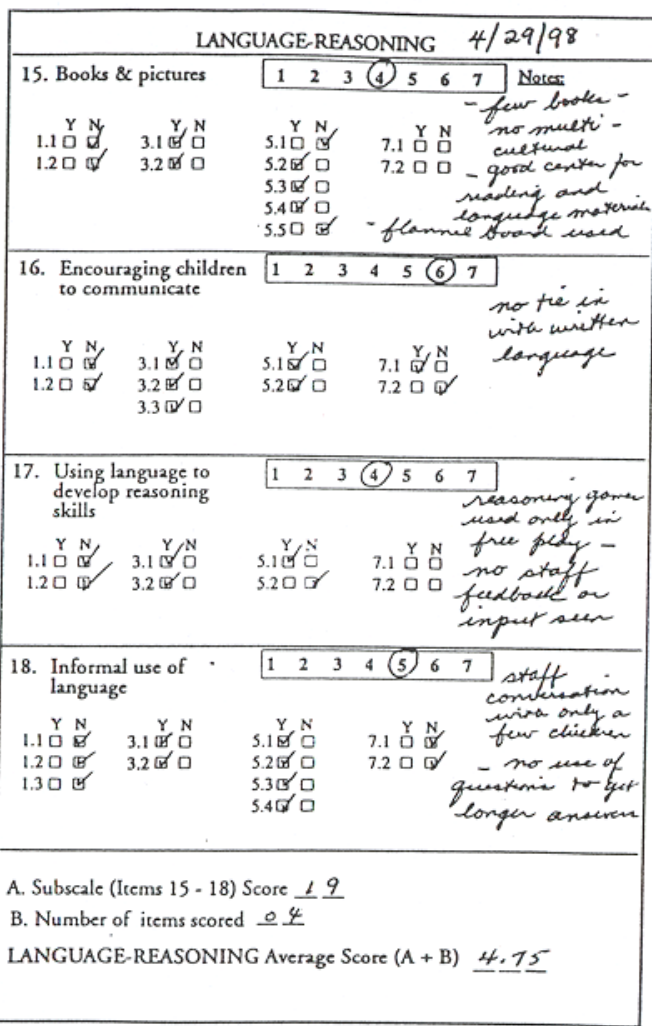

Sample of a Profile

III. Language-Reasoning

$$
\text { (15-18) }
$$

\begin{tabular}{|l|l} 
Obs. 1 & Obs. 2 \\
\hline 3 & 4,75 \\
\hline
\end{tabular}

average subscale

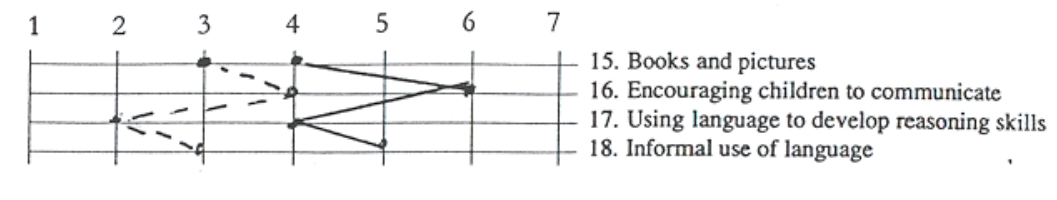




\section{Appendix B}

Examples of Individualized Training Plans 


\section{Classroom Report of Scores}

Center

Classroom

ECERS Scores Observation 1 Compared to Observations 2

Space and Furnishings

ECERS 1

ECERS 2

1. Indoor Space

2. Furnishings (routine)

3. Furnishings (relax)

4. Room Arrange (play)

5. Space for Privacy

6. Child related Display

7. Space for Gross Motor

8. Motor Equipment

Personal Care Routines

9. Greeting/Departure

10. Meals/Snacks

11. Nap/Rest

12. Toileting

13. Health Practices

14. Safety Practices

\section{Language-Reasoning}

15. Books and Pictures

16. Encouraging Child to Communicate

17. Use Lang. To Dev. Reasoning Skills

18. Informal Use of Language 


\section{Activities}

19. Fine Motor

20. Art

21. Music/Movement

22. Blocks

23. Sand/Water

24. Dramatic Play

25. Nature/Science

26. Math/ Number

27. Use of TV, Video, Computers

28. Promoting acceptance of diversity

\section{Interaction}

29. Supervision of Gross Motor Activities

30. General Supervision of Children

31. Discipline

32. Staff-Child Interaction

33. Interaction among children

\section{Program Structure}

34. Schedule

35. Free Play

36. Group Time

37. Provisions for children w/ Disabilities 
Parents and Staff

38. Provisions for Parents

39. Provisions for Personal Needs of Staff

40. Provisions for Profess. Needs of Staff

41. Staff interaction and cooperation

42. Supervision and Evaluation of Staff

43. Opportunities for Professional Growth 
ECERS-R Overall Score

Center:

Classroom:

Overall Score Observation 1:

\begin{tabular}{|l|l|}
\hline Space and Furnishings: & \\
\hline Overall Score: & \\
\hline $\begin{array}{l}\text { 1. Indoor Space: Score: } \\
\text { Goals to work on: }\end{array}$ & $\begin{array}{l}\text { Responsible person for } \\
\text { Goals: }\end{array}$ \\
\hline $\begin{array}{l}\text { 2. Furniture for routine care...: Score: } \\
\text { Goals to work on: }\end{array}$ & $\begin{array}{l}\text { Responsible person for } \\
\text { Goals: }\end{array}$ \\
\hline $\begin{array}{l}\text { 3. Furnishings for Relaxation: Score: } \\
\text { Goals to work on: }\end{array}$ & $\begin{array}{l}\text { Responsible person for } \\
\text { Goals:_- }\end{array}$ \\
\hline $\begin{array}{l}\text { 4. Room Arrangement for Play: Score: } \\
\text { Goals to work on: }\end{array}$ & $\begin{array}{l}\text { Responsible person for } \\
\text { Goals: }\end{array}$ \\
\hline $\begin{array}{l}\text { 7. Space for gross motor play: Score: } \\
\text { Goals to work on: }\end{array}$ & $\begin{array}{l}\text { Responsible person for } \\
\text { Goals: }\end{array}$ \\
\hline $\begin{array}{l}\text { 5. Space for Privacy: Score: } \\
\text { Goals to work on: }\end{array}$ & $\begin{array}{l}\text { Responsible person for } \\
\text { Goals: }\end{array}$ \\
\hline \\
\hline
\end{tabular}




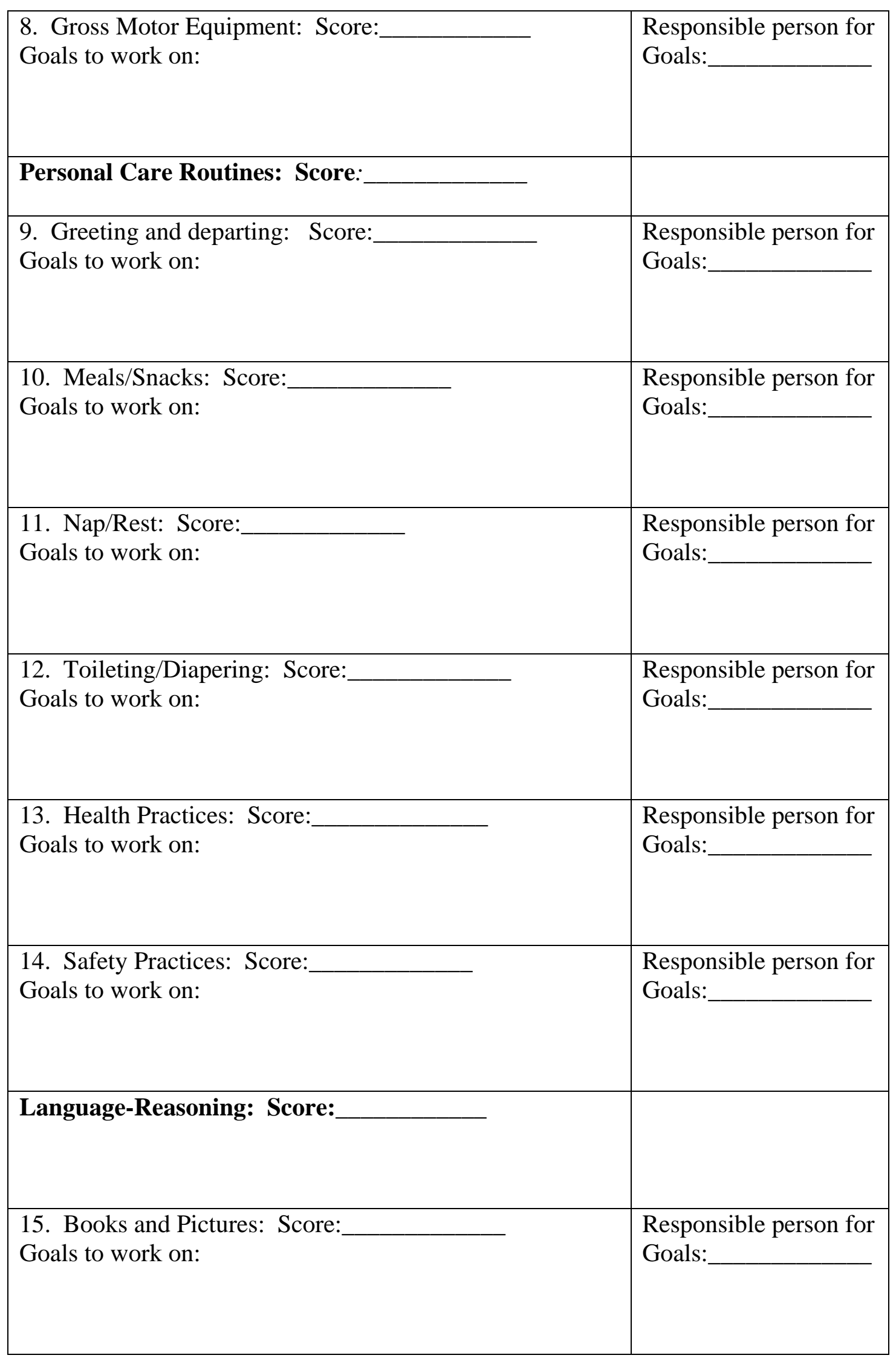




\begin{tabular}{|c|c|}
\hline $\begin{array}{l}\text { 16. Encouraging Children to Communicate: Score: } \\
\text { Goals to work on: }\end{array}$ & $\begin{array}{l}\text { Responsible person for } \\
\text { Goals: }\end{array}$ \\
\hline $\begin{array}{l}\text { 17. Using Lang. To Dev. Reasoning Skills: Score: } \\
\text { Goals to work on: }\end{array}$ & $\begin{array}{l}\text { Responsible person for } \\
\text { Goals: }\end{array}$ \\
\hline $\begin{array}{l}\text { 18. Informal Use of Language: Score: } \\
\text { Goals to work on: }\end{array}$ & $\begin{array}{l}\text { Responsible person for } \\
\text { Goals: }\end{array}$ \\
\hline Activities: Score: & \\
\hline $\begin{array}{l}\text { 19. Fine Motor: Score: } \\
\text { Goals to work on: }\end{array}$ & $\begin{array}{l}\text { Responsible person for } \\
\text { Goals: }\end{array}$ \\
\hline $\begin{array}{l}\text { 20. Art: Score: } \\
\text { Goals to work on: }\end{array}$ & $\begin{array}{l}\text { Responsible person for } \\
\text { Goals: }\end{array}$ \\
\hline $\begin{array}{l}\text { 21. Music and Movement: Score: } \\
\text { Goals to work on: }\end{array}$ & $\begin{array}{l}\text { Responsible person for } \\
\text { Goals: }\end{array}$ \\
\hline $\begin{array}{l}\text { 22. Blocks: Score: } \\
\text { Goals to work on: }\end{array}$ & $\begin{array}{l}\text { Responsible person for } \\
\text { Goals: }\end{array}$ \\
\hline $\begin{array}{l}\text { 23. Sand/Water: Score: } \\
\text { Goals to work on: }\end{array}$ & $\begin{array}{l}\text { Responsible person for } \\
\text { Goals: }\end{array}$ \\
\hline
\end{tabular}




\begin{tabular}{|c|c|}
\hline $\begin{array}{l}\text { 24. Dramatic Play: Score: } \\
\text { Goals to work on: }\end{array}$ & $\begin{array}{l}\text { Responsible person for } \\
\text { Goals: }\end{array}$ \\
\hline $\begin{array}{l}\text { 25. Nature/Science: Score: } \\
\text { Goals to work on: }\end{array}$ & $\begin{array}{l}\text { Responsible person for } \\
\text { Goals: }\end{array}$ \\
\hline $\begin{array}{l}\text { 26. Math/Number: Score: } \\
\text { Goals to work on: }\end{array}$ & $\begin{array}{l}\text { Responsible person for } \\
\text { Goals: }\end{array}$ \\
\hline $\begin{array}{l}\text { 27. Use of TV, Video, Comput.: Score: } \\
\text { Goals to work on: }\end{array}$ & $\begin{array}{l}\text { Responsible person for } \\
\text { Goals: }\end{array}$ \\
\hline $\begin{array}{l}\text { 28. Promoting Acceptance of Diversity: Scores: } \\
\text { Goals to work on: }\end{array}$ & $\begin{array}{l}\text { Responsible person for } \\
\text { Goals: }\end{array}$ \\
\hline Interaction: Score: & \\
\hline $\begin{array}{l}\text { 29. Supervision of Gross Motor: Score: } \\
\text { Goals to work on: }\end{array}$ & $\begin{array}{l}\text { Responsible person for } \\
\text { Goals: }\end{array}$ \\
\hline $\begin{array}{l}\text { 30. General Supervision of Children: Score: } \\
\text { Goals to work on: }\end{array}$ & $\begin{array}{l}\text { Responsible person for } \\
\text { Goals: }\end{array}$ \\
\hline $\begin{array}{l}\text { 31. Discipline: Score: } \\
\text { Goals to work on: }\end{array}$ & $\begin{array}{l}\text { Responsible person for } \\
\text { Goals: }\end{array}$ \\
\hline
\end{tabular}




\begin{tabular}{|c|c|}
\hline $\begin{array}{l}\text { 32. Staff-Child Interactions: Score: } \\
\text { Goals to work on: }\end{array}$ & $\begin{array}{l}\text { Responsible person for } \\
\text { Goals: }\end{array}$ \\
\hline $\begin{array}{l}\text { 33. Interaction among children: Scores: } \\
\text { Goals to work on: }\end{array}$ & $\begin{array}{l}\text { Responsible person for } \\
\text { Goals: }\end{array}$ \\
\hline \multicolumn{2}{|l|}{ Program Structure: Score: } \\
\hline $\begin{array}{l}\text { 34. Schedule: Score: } \\
\text { Goals to work on: }\end{array}$ & $\begin{array}{l}\text { Responsible person for } \\
\text { Goals: }\end{array}$ \\
\hline $\begin{array}{l}\text { 35. Free Play: Score: } \\
\text { Goals to work on: }\end{array}$ & $\begin{array}{l}\text { Responsible person for } \\
\text { Goals: }\end{array}$ \\
\hline $\begin{array}{l}\text { 36. Group time: Scores: } \\
\text { Goals to work on: }\end{array}$ & $\begin{array}{l}\text { Responsible person for } \\
\text { Goals: }\end{array}$ \\
\hline $\begin{array}{l}\text { 37. Provisions...Disabilities: Score: } \\
\text { Goals to work on: }\end{array}$ & $\begin{array}{l}\text { Responsible person for } \\
\text { Goals: }\end{array}$ \\
\hline \multicolumn{2}{|l|}{ Parents and Staff: Overall Score: } \\
\hline $\begin{array}{l}\text { 38. Provisions for Parents: Score: } \\
\text { Goals to work on: }\end{array}$ & $\begin{array}{l}\text { Responsible person for } \\
\text { Goals: }\end{array}$ \\
\hline
\end{tabular}




\begin{tabular}{|l|l|}
\hline $\begin{array}{l}\text { 39. Provisions for personal needs of Staff: Score: } \\
\text { Goals to work on: }\end{array}$ & $\begin{array}{l}\text { Responsible person for } \\
\text { Goals: }\end{array}$ \\
\hline $\begin{array}{l}\text { 40. Provisions for professional needs: Score: } \\
\text { Goals to work on: }\end{array}$ & $\begin{array}{l}\text { Responsible person for } \\
\text { Goals: }\end{array}$ \\
\hline $\begin{array}{l}\text { 41. Staff interaction and cooperation: Score: } \\
\text { Goals to work on: }\end{array}$ & $\begin{array}{l}\text { Responsible person for } \\
\text { Goals: }\end{array}$ \\
\hline $\begin{array}{l}\text { 42. Supervision and evaluation of Staff: Score: } \\
\text { Goals to work on: }\end{array}$ & $\begin{array}{l}\text { Responsible person for } \\
\text { Goals: }\end{array}$ \\
\hline $\begin{array}{l}\text { 43. Opportunities for Prof. Growth: Score: } \\
\text { Goals to work on: }\end{array}$ & $\begin{array}{l}\text { Responsible person for } \\
\text { Goals: }\end{array}$ \\
\hline
\end{tabular}


Appendix C

Vita 


\section{Brittany Kathleen Lucci \\ 204 Rhode Island Avenue, Westover West Virginia 26501 \\ (304) 291-4913 \\ bitty002@aol.com}

\section{EDUCATION:}

West Virginia University, Morgantown, West Virginia Master's of Science in Family and Consumer Sciences

August 2002-May 2004

West Virginia University, Morgantown, West Virginia

Bachelor's of Sciences in Family and Consumer Sciences

August 1998-May 2002

\section{EXPERIENCE:}

Graduate Teaching Assistant

West Virginia University, Child Development Laboratory

Morgantown, West Virginia 26506

August 2002-May 2004

- Worked under Dr. Bobbie G. Warash

- Supervised interns and students

- Implemented lesson plans with preschool children

- Aided preparation of each semester's students

- Trained interns on the use of the Early Childhood Environmental Rating Scale

- Assisted in the training of interns and other students

Head Start National Reporting System (NRS) Assessor

Monongalia County School Board of Education, Monongalia County Federal Programs Morgantown, West Virginia 26501

October 2003-May 2004

- Assessed Head Start children using the NRS testing manual

- Reported data to Cindy O’Brien

Early Childhood Environmental Rating Scale (ECERS) Assessor for the EDUCARE Project Marshall University and EDUCARE

Huntington, West Virginia

September 2001-February 2002

- Collected data using the ECERS in EDUCARE schools in Monongalia County

- Reported data to Dr. Bobbie G. Warash 


\section{VITA (Continued)}

\section{ACTIVITIES AND HONORS:}

- West Virginia Association for Young Children Student Chapter, President (May 2002-May 2004)

- Gamma Sigma Delta Honor Society, West Virginia Chapter (2004-Present)

- West Virginia Association for Young Children, Student Chapter, Secretary (1999-2002)

- West Virginia University Davis College of Agriculture, Forestry, and Consumer Sciences Honors for Outstanding Scholarship and Leadership, Dean's List (Spring 2002, Spring \& Fall 2001, \& Fall 1999)

- Division of Family and Consumer Sciences 2002 Outstanding Senior Award (2002)

- Outstanding Achievement Award in Child Development and Family Studies (2001/2002)

- Presidential Award for Excellence in Scholarship (2000)

\section{REFERENCES:}

Available upon request 